\title{
Economic Diversity and the Resource Curse: A Dynamic Panel Model
}

\author{
Bankole Fred Olayele* \\ Carleton University
}

\author{
Kwok Tong Soo ${ }^{\dagger}$ \\ Lancaster University
}

April 2018

\begin{abstract}
This paper contributes to the debate on the impact of economic diversity and the resource curse on economic growth. We use dynamic panel data models on data on Canadian and US subnational jurisdictions. We find evidence for a positive relationship between diversity and growth. Based on the Krugman Specialization Index, our analysis shows that the required threshold for not having the resource curse is 0.209 . Above this threshold, the marginal contribution of natural resources to economic growth is lower for a more diversified regional economy than a less diversified one. We highlight the policy implications of these findings.
\end{abstract}

JEL Classification: O13; R11.

Key words: Diversity; resource curse; economic growth.

\footnotetext{
* Sprott School of Business, Carleton University, Ottawa K1S 5B6, Canada. Email: fred.olayele@ carleton.ca

$\dagger$ Department of Economics, Lancaster University Management School, Lancaster LA1 4YX, United Kingdom.

Email:k.soo@lancaster.ac.uk
} 


\section{Introduction}

Economic diversification remains a recurring theme in public policy debates; it is popularly believed to be the cure to the "resource curse" challenge. The benefits of diversification, as well as the importance of key economic, demographic, geographic and institutional factors that explain it, remain widely acknowledged. However, explaining why diversification helps some economies to succeed where others fail remains a mirage. To further complicate things, most empirical investigations of the relationship between economic growth and diversity provide inconclusive evidence. For instance, concerns continue to be raised on the effects of commodity price shocks on resource-dependent economies across the world. To the extent that volatile prices have affected government revenues, output and capital investment, the policy debate on whether or not economic diversification can help in escaping the resource curse is back in many resource-rich and resource-dependent jurisdictions.

This paper aims at contributing to the debate on economic diversity, the resource curse and economic growth, using data on Canadian and US sub-national jurisdictions, and employing recent techniques of dynamic panel data (DPD) models. The objectives are two-fold and we achieve them by estimating a conditional growth model in a regional context. First, we examine the relationship between economic diversification and growth for Canadian and US jurisdictions over the 1987-2010 period. Humphreys, Sachs and Stiglitz (2007), Collier and Venables (2007), Gelb (2010) and Gelb and Grasmann (2010), among others, postulate that economic diversification is a potent long-term strategy that can help resource-endowed and resourcedependent jurisdictions escape the resource curse. However, some existing results show (e.g. Ahmadov, 2012) that many jurisdictions that follow this trajectory have little or nothing to show for diversification.

Our second objective is to employ an empirical growth model to explain growth in real per capita income at the US state and Canadian provincial level as a function of natural resources. Sachs and Warner (1995) argue that an indirect consequence of natural wealth is the resource curse. Contemporary evidence on the curse yields a conundrum (Collier and Goderis, 2007); most recent studies conclude that the transmission mechanism of the curse is important in determining the presence of the resource curse.

In the next section, we review the existing literature. This is followed in Section 3 by a discussion of the data and methods used. Section 4 presents the results, while Section 5 provides some concluding comments.

\section{Literature Review}

\subsection{The Resource Curse}

The resource curse may be stated as follows: It is the paradox that countries with an abundance of natural resources, tend to have less economic growth, than countries with fewer natural resources. The resource curse has two common explanations in the literature: (i) economic and (ii) political-institutional. The pioneering research of Corden and Neary (1982) forms the basis of the theory of Dutch disease. The "Dutch disease" - a situation that leads to a diminished 
importance of the manufacturing sector due to the crowding out effect of natural resources - is the major economic explanation of the curse.

Corden and Neary (1982) use a two-factor model to explain what can cause a decrease in the competitiveness of the trade-exposed manufacturing sector. They assume a small open economy with three sectors: a non-tradable sector (service sector), an import-competing manufacturing sector and a resource sector. Corden and Neary conclude that the resource boom will affect the rest of the economy through two channels: the effect of movement of manufacturing resources and the expenditure effect. This leads to a lagging export sector which suffers through deindustrialization.

Sachs and Warner (1995), who formally established the resource curse, support a dynamic version of the Dutch disease model by showing that on average, resource-abundant countries lag behind countries with less resources. Using the ratio of natural resource exports to GDP as a proxy for natural resource endowment, and 1971 as the base year, they control for other determinants of economic growth such as initial per capita income, trade policy, government efficiency, and investment rates.

Auty and Mikesell (1998) examine the problems faced by mineral-rich countries in achieving sustainable development, compared to their mineral-deficient neighbours. Focusing on nine countries - Botswana, Chile, Colombia, Indonesia, Jamaica, Namibia, Papua New Guinea, Peru and Trinidad and Tobago - Auty and Mikesell offer a compelling argument on why nurturing the economic and social conditions that sustain economic growth is more important than the sustainability of mineral production itself.

The second popular explanation is the political-institutional explanation. This model blames the existence of the curse on rent-seeking behaviour. Robinson, Torvik and Verdier (2006) present a formal political-economy framework of the resource curse by arguing that in order to understand whether or not natural resources are a blessing or a curse, it is imperative to analyze the political incentives that resource endowments generate, through a careful analysis of the interaction between institutions and resources. In order to fully analyze the effects of temporary and permanent resource booms, they use a two-period probabilistic model to consider some stock of natural resources with an intertemporal path of prices subject to exogenous price variation capturing the environment faced by small developing economies subject to international commodity price variations.

Robinson et al. (2006)'s analysis reveals a complex relationship between resource extraction and the political environment. Where there are weak political institutions, resource booms will lead, through the political process, to inefficient resource allocations. They conclude that the extent to which the predictions in their model generate the curse is determined by the quality of institutions since countries with strong institutions benefit from resource booms, while those without suffer from the curse. Lane and Tornell (1999) and Torvik (2002) explain this further using theoretical models of rent seeking. Isham, Woolcock, Pritchett and Busby (2005) look at this issue from the perspective that resource rents may create a wealthy class of elites who may be opposed to welfare-improving economic and political reforms. 
While corruption and rent seeking are less prevalent in developed countries compared to their developing counterparts, Ross (2001) cautions that resource-dependent jurisdictions may tax their residents less heavily, and in turn, tax payers may be indifferent to politicians' accountability and representation. In our case, Ross' note becomes important when we consider Alberta and Alaska, two important oil and gas jurisdictions in Canada and the US, respectively, that do not levy sales tax - an important component of consumption tax. Béland and Tiagi (2009) conclude that for any given revenue target, the incentive to tax residents decreases when natural resource rents are easily accessible. Putnam (1993) and Inglehart (1997) amplify this sentiment; they argue that this produces citizens who care less about how accountable politicians are.

In an attempt to improve on the influential work of Sachs and Warner, Mehlum, Moene and Torvik (2006) contrast the findings of Sachs and Warner that institutions are not decisive for the resource curse by using the latter's data and methodology to test the hypothesis that institutions are actually decisive for the resource curse. Using the average growth rate of real GDP per capita from 1965 to 1990 as the dependent variable, and an unweighted average of five indexes (rule of law, bureaucratic quality, corruption in government, risk of expropriation and government repudiation of contract) as a proxy for institutional quality, they demonstrate that countries with good institutional quality will not experience any resource curse, as natural resources only inhibit economic growth in countries with 'grabber friendly' institutions and not in countries with 'producer friendly' institutions.

Mehlum et al. (2006) go beyond the regressions of Sachs and Warner by providing an alternative explanation for understanding the resource curse through the inclusion of an interaction term: [resource abundance] x [institutional quality], that captures their model's prediction that it is only when institutions are weak that resource abundance is harmful to growth. In addition to finding a positive coefficient for the interaction term, the empirical results show that countries with institutional quality index higher than the threshold value of 0.93 do not experience the resource curse. 15 out of the 87 countries included in the regression have institutional quality strong enough to neutralize the resource curse.

\subsection{The Case for Economic Diversification}

Gelb (2010) addresses an important question: why should a country diversify? Or, why should a country try to move away from its existing comparative advantage? His answer is that export diversification is associated with higher long-run growth. However, resource exporters are different in many dimensions, and these differences will shape diversification priorities and policies. Regional economic diversification has been shown to be a potent tool for advancing technological progress, innovation, positive technology externalities and other sources of agglomeration economies (Jacobs, 1969; Feldman and Audretsch, 1999). It prompts firms to compete for scarce resources, and in the process, promotes innovation (Porter, 1990). However, evidence on the diversity-growth debate is inconclusive. While Attaran (1986), for instance, fails to find any relationship between diversity and per capita income growth at the state level, Attaran and Zwick (1987) conclude that such relationship does, in fact, exist at the county level for the 
State of Oregon. Frenken, Van Oort and Verburg (2007) and Bishop and Gripaios (2010) use employment growth in place of per capita income growth, and conclude with divergent views.

Hackbart and Anderson (1975) look at the diversity-growth argument from the point of view of stability. They suggest that economic diversity makes regions less susceptible to the volatility inherent in business cycles. Dissart (2003) shares the same view. The central argument of these researchers is that stability is conducive for regional economic growth to the extent that displaced workers from other sectors of the economy can be easily absorbed by a diverse economy, compared to a highly specialized one. Bishop and Gripaios (2010) say specialization has a negative impact on growth, while the economic diversity effect is heterogeneous across sectors; Frenken et al. (2007) summarize their results thus: related variety enhances employment growth, while other types of agglomeration economies do not matter.

From the foregoing, the importance of the resource-diversity-growth debate in helping shape the direction of policy in resource-based economies cannot be overemphasized. This paper fits into the various discussions so far because it is an extension of many of the studies cited above. Gelb (2010) makes an important contribution to the resource-diversity debate by pointing out the following three main complications in the debate: (i) how to deal with the endogeneity of measures of resource abundance and resource dependence (ii) how to measure outcomes (income levels, growth rates or broader development indicators) and (iii) how to allow for country heterogeneity. Our sub-national focus and GMM estimation strategy enable us to deal with all three issues, in addition to providing updated results.

\section{Data and Descriptive Analysis}

\subsection{Data Sources}

Our data are compiled from the following sources: US Bureau of Economic Analysis (Regional Economic Accounts), Statistics Canada (Provincial Economic Accounts and Labour Force Survey), World Bank (National Accounts Data), OECD (National Accounts Data Files), Economic Freedom of North America (Fraser Institute) and the Bank of Canada (Rates and Statistics - Annual Average Exchange Rates. Canadian data are converted into US dollars using annual Canada-US average nominal exchange rates. Our sample is a panel data set spanning eight three-year intervals from 1987 to 2010 and covering all 10 Canadian provinces and 50 states of the US. GDP data for the 1987-1997 period for all 60 jurisdictions are based on the SIC system, while 1998-2010 data are based on the NAICS. We use the following 3-year averages: 1987 - 1989; 1990 -1992; 1993 - 1995; 1996 -1998; 1999 - 2001; 2002 - 2004; 2005-2007; 2008 -2010. This gives rise to $\mathrm{N}=60 ; \mathrm{T}=8$. In the regression itself, $\mathrm{T}$ becomes 7 because we lose one complete data set to per capita real GDP growth rate calculation. Hence we have 420 observations.

\subsection{Construction of Variables}

One important issue in the resource curse literature is the debate about which resource proxies to use. Among other things, the notion exists that abundant natural resources in a region may not necessarily translate to a large share of exports, employment or income. In the words of 
Pendergast, Clarke and van Kooten (2008), "As a country develops other sectors of its economy, the share of natural resources in exports, employment and wealth should fall" (p.10). Since the pioneering work of Sachs \& Warner in 1995, the share of primary production in exports (or in GDP) has been the most widely used measure. For instance, Mehlum et al. (2006) follow Sachs and Warner. This measure is not without shortcomings. Bulte, Damania and Deacon (2005) point out that as a flow, this proxy will be inadequate as a measure of a jurisdiction's real stock of natural resources. The problem inherent in choosing more precise resource abundance stock measures, however, is the difficulty in measuring them, in addition to the fact that "the possible effects through which the curse takes place cannot be expected to happen until the resources are extracted" (Torres, Afonso and Soares, 2013; p.8).

A number of papers have assessed the robustness of the resource curse correlation to alternative measures of resource abundance and dependence, as well as the estimation methods employed (e.g. Gylfason, 2001; Ding and Field, 2005; Papyrakis and Gerlagh, 2007; Pendergast et al., 2008; Boyce and Emery, 2011 and James and Aadland, 2011). Gylfason proposes three proxies: (1) the share of primary exports in total exports (or in GDP); (2) the share of employment in primary production in total employment; and (3) the share of natural capital in national wealth. Ding and Field (2005) use the World Bank's estimation of natural capital (i.e. natural-resource capital as a percentage of total capital or as a percentage of the population) as a measure of a country's resource endowment. For their cross-country study, Pendergast et al. use fuel exports per capita, ores/metals exports per capita and forestry production per capita. Using data for US states over the 1970-2001 period, Boyce and Emery derive the share of employment in the exhaustible resource sector as mining employment divided by total employment for each state.

In light of the above, we follow Gylfason, Boyce and Emery and Sachs and Warner and use the following two alternative measures of natural resources: (1) mining as a share of GDP and (2) mining as a share of total employment. We assess the robustness of the resource curse correlation to our alternative measures of natural resources and estimation methods. Data on mining as a share of GDP are sourced from Statistics Canada (Labour Force Survey) and the Bureau of Economic Analysis ((Regional Economic Accounts) based on the NAICS estimates of GDP by industry for the provinces and the states.

Our first control variable (which also serves as the alternative institutional quality measure), educational attainment $E D U_{i t}$, is defined as the percent of persons 25 years and over who have completed at least a Bachelor's degree. Educational attainment is closely related to the skills and competencies of a country's population, and could be seen as a proxy of both the quantitative and qualitative aspects of the stock of human capital. Data on educational attainment for all Canadian provinces come from Statistics Canada's Labour Force Survey (LFS), CANSIM Table 282-0004. Corresponding educational attainment data for US states are obtained from the US Census Bureau, American Community Survey (ACS). ACS provides estimates of educational attainment for US states on an annual basis from 2000 onwards; prior to this time, only 1990 data are available. Hence we interpolate the earlier data to obtain our 1997 measure of educational attainment for US states.

Mankiw, Romer and Weil (1992) show that physical capital accumulation is an important determinant of economic growth. The variable of interest here is $C A P_{i t}$, our measure of the 
capital stock endowments in jurisdiction $i$ at time $t . C A P_{i t}$ is the ratio of capital stock to real GDP. Following Yamarik (2011) and Hall and Jones (1999), we construct our capital stock series using the perpetual inventory method (PIM):

$$
K_{t}=K_{t-1}-\delta K_{t-1}+G F K_{t}=(1-\delta) K_{t-1}+G F K_{t}
$$

where $K_{t}$ is capital stock level at time $t, G F K_{t}$ is gross fixed capital formation at time $t$ and $\delta$ is the rate of depreciation (which is assumed constant over time). To implement the PIM, the size and time profile of depreciation rates, gross investment time series and an initial level of capital stock are required. We construct the initial capital stock using Hall and Jones' formula:

$$
K_{0}=\frac{G F K_{0}}{\delta+g_{G F K}}
$$

where $K_{0}$ is the initial capital stock, $G F K_{0}$ is the level of gross fixed capital formation in the initial period, $g_{G F K}$ is the average annual geometric growth rate of $G F K$, and $\delta$ is as previously defined. We assume that capital stocks depreciate at a constant rate of $6 \%$, in line with Hall and Jones.

Canadian provincial capital stock data are calculated using the PIM discussed above, with data on business gross fixed capital formation - the private sector portion of total GFK. We use GFK data for estimating the initial capital stock. Our $g_{G F K}$ value ${ }^{1}$ is taken as $3.6 \%$ - based on the average of Statistics Canada's old and new capital stock annual growth rates. Equivalent capital stock data for US states are based on Yamarik's net private capital stock data ${ }^{2}$ constructed for the 50 states. Since Yamarik's data are available only up to 2007, we assume that capital stock and GDP grew at the same rate for the 2008 - 2010 period. We therefore use the growth rates of real GDP to derive the capital stock figures for 2008, 2009 and 2010.

There is no consensus on which index is the best proxy for diversity or specialization (Palan, 2010). Of the many possible approaches available to examine a regional economy's degree of relative industrial specialization, comparing the distribution of employment across industries in the region with that of the nation is one popular strategy. Under this arrangement, the sectoral composition of the nation's employment defines the limits of diversification. It is thus expected that a region's employment will be more specialized (and by implication less diversified) than that of the "parent" nation. This framework reflects the degree of similarity between regional and national industrial structures, and is based on the notion that the national economy is fully diversified.

\footnotetext{
${ }^{1}$ Statistics Canada uses 3.58\% and 3.65\% as the old and new capital stock annual growth rates, respectively.

${ }^{2}$ https://web.csulb.edu/ syamarik/
} 
Table 1: NAICS Industry Sectors

\begin{tabular}{ll}
\hline a) & Agriculture, forestry, fishing, and hunting \\
b) & Mining \\
c) & Construction \\
d) & Manufacturing \\
e) & Wholesale trade \\
f) & Retail trade \\
g) & Transportation, warehousing and utilities \\
h) & Finance, insurance, real estate, rental and leasing \\
i) & All other services, except public administration \\
j) & Government and government enterprises \\
\hline
\end{tabular}

Notes: The estimates of employment for 1998-2006 are based on the 2002 NAICS; the estimates for 2007-2010 are based on the 2007 NAICS. In line with the various changes to the NAICS over time, we combine some sectors and slightly modify sector names for others in order to allow for uniformity between certain Canadian and US sectors. For instance, the finance and insurance sector (NAICS code 1000) and the real estate and rental and leasing sector (NAICS code 1100) are combined. The agriculture, forestry, fishing and hunting sector in Canada captures the same information as the forestry, fishing and related activities sector in the US; we use the former name since it is more encompassing.

In regional economic analysis, it is common practice to model diversity using employment distribution across industry sectors. We use employment data covering 10 industry sectors from the Bureau of Economic Analysis (Regional Economic Accounts) and Statistics Canada (Labour Force Survey). Our employment variable is the annual employment in full-time equivalents. Some authors (e.g. Palan, 2010) suggest the use of an alternative variable (which is less prone to productivity biases) to test the robustness of the indices of specialization. A top candidate here is GDP. We construct these indices based on GDP in order to assess robustness. Results for this alternative measure are presented along with the main employment-based measure.

To assess the robustness of our results to different measures of diversity, we use five leading indices - two versions of the Ogive Index, the Entropy Index, the Hirschman-Herfindahl Index (HHI) and the Krugman Index. These indices have become popular in empirical regional specialization studies (e.g. Traistaru, Nijkamp and Longh; 2002, Ezcurra, Pascual and Rapún; 2006, and Palan; 2010) because of the relative ease with which they are computed. We make use of data across 10 industry sectors. These include four goods-producing sectors, and six servicesproducing sectors. The 10 sectors are presented in Table 1.

\subsection{Diversity Indices}

Palan (2010) compares and discusses the characteristics of various specialization indices across 51 industries in 24 European countries by classifying the indices into two broad groups. She reiterates that heterogeneity levels not only vary between these groups, but also within. Her conclusion is that policy makers should exercise great care in the choice of indices included in empirical economic diversity studies. Palan's two groups are: (i) absolute specialization measures, and (ii) relative specialization measures. The first group (also called specialization indices) is based on the notion that a region is considered specialized if a small number of industries exhibit high shares of the overall employment of the country (Palan, 2010). This would be the case for the Canadian province of Saskatchewan, for instance, which specializes in 
the production of minerals, oil and gas, and food. Or the US state of Alaska, where the dominant economic activity is oil and gas. The Entropy, Hirschman-Herfindahl and both versions of the Ogive indices fall under this category.

On the other hand, relative specialization measures (also called heterogeneity indices) are based on the deviation of a region's industry structure from the average industry structure of the reference group of regions. As measured in this paper through the Krugman Index, this measure sheds more light on the comparative advantages that exist in different regional economies, compared to the reference group. For example, consider the Canadian province of Saskatchewan. Saskatchewan is relatively more specialized in potash mining than any other province, although the absolute share of this industry in the Saskatchewan economy is low. Therefore, specialization and heterogeneity indices would indicate high and low degrees of specialization, respectively, when a region is specialized in industries which the other countries are also specialized in (Palan, 2010).

The HHI is one of the most commonly used indicators of specialization. Initially used as an indicator of market concentration in the industrial organization literature (Scherer, 1980), others have used it in economic diversity and macroeconomic specialization studies (e.g. Tauer, 1992; Davis, 1998; Storper, Chen and De Paolis, 2002; and Beine and Coulombe, 2007). The HHI shows the degree of dominance of a certain industry in a regional economy. It is expressed as follows:

$$
H H I_{i}=\sum_{i=1}^{N} S_{i}^{2}
$$

where $S_{i}$ is employment share in the $i$ th industry. The index increases with the degree of specialization, and reaches its upper limit of 1 when region $i$ is specialized in only one industry. The lowest level of specialization is indicated by $1 / N$ i.e. the lowest degree of specialization indicated by an equiproportional employment share for each industry. In our case, the lower bound is 1/10. Palan (2010) echoes Hall and Tideman's (1967) view that in general, the relative sizes of industries are more important than the absolute number of industries, for the absolute value of the HHI. This motivates the use of relative employment share as the weighting factor for each industry.

The basic tenet of the Ogive index derives from the notion that the more diversified a sector is, the less concentrated it is and the more competitive it becomes. In tune with Malizia and $\mathrm{Ke}$ (1993), therefore, a more diversified regional economy is that which has a more even distribution of economic activity. McLaughlin (1930) and Tress (1938) were among the first to use this. There are two popular variants of this index; they are differentiated based on the weight attached to the penalty function used to measure industry share deviations from the uniform distribution benchmark.

The simpler version of the index is based on a penalty function of absolute values (Jackson, 1984; Tran, 2011). We call this the Absolute Ogive Index (AGV) and is given as:

$$
A G V_{i}=\sum_{i=1}^{N}\left(S_{i}-\frac{1}{N}\right)
$$


There is also a more advanced version of the Ogive index based on a quadratic function which in turn uses the factor $1 / N$ as a denominator in order to avoid extremely low value scenarios common with squared fractions. This is the Quadratic Ogive Index (QGV) and is given as:

$$
Q G V_{i}=\sum_{i=1}^{N} \frac{\left(S_{i}-1 / N\right)^{2}}{1 / N}
$$

Again, $N$ is the number of industries in the regional economy, and $S_{i}$ is the industry share of economic activity for the $i^{\text {th }}$ sector. The lower bound of both indices is obtained with equiproportional employment shares for all $N$ industries; this gives the value of zero and reflects a perfect diversity case. A perfect specialization scenario arises at the other extreme when the upper bound of the simple and advanced indices in (4) and (5) above are $(N-1) / N$ and $(N-1)^{2} / N$, respectively.

Following Pede (2013), the fourth diversity measure we use is based on the law of entropy. Entropy measures disorder or uncertainty in physical phenomena; in economics, it is used as a proxy for the distribution of economic activity across industry sectors. The entropy approach was pioneered by Garrison and Paulson (1973) for use in economics, and has been used in numerous studies related to diversity and employment stability (e.g. Attaran, 1986 and Malizia and Ke, 1993). The Entropy (ENT) index is:

$$
E N T_{i}=\sum_{i=1}^{N}\left(S_{i}\right) \ln \left(\frac{1}{S_{i}}\right)
$$

This is premised on the assumption of equiproportional levels of economic activity in all industries - i.e. the notion of ideal diversity. The economic diversification process for a region that experiences perfect diversity is modeled as a state of equilibrium or optimum. As for the Ogive index, equiproportional employment shares for all $N$ industries reflect a perfect diversity case. At the other extreme is perfect specialization, which arises with the assumption of employment concentration in just one industry - resulting in a value of zero for the Entropy index. In this paper, the range for the Entropy index is zero to 2.303; the latter value being the value of the natural logarithm of 10, our industry number. Higher values of this index imply higher degrees of diversity.

The Krugman Specialization Index (KSI), also called the Krugman Dissimilarity Index (KDI), calculates the share of employment that needs to be relocated in order to achieve an industry structure equivalent to the average structure of the reference group (Palan, 2010). In other words, it measures the standard error of industry shares. A major advantage with this index is in the ability to compare one industry with the overall economy. The KSI is:

$$
K S I=\sum_{i=1}^{N}\left|S_{i j}-S_{j}\right|
$$

The value of KSI ranges between zero and $2(N-1) / N$. When the economic structure of one region is the same as that of the reference economy, $K S I=0$. A higher KSI implies a higher deviation of the economic structure of a region from the national average; the more such a region is considered to be specialized (Palan, 2010). Compared to the four absolute specialization measures discussed earlier, a region with a more homogenous structure - compared to a highly 
specialized national group - will receive a high KSI value. On the other hand, we would obtain a lower KSI value for a regional economy that specializes in similar industries as the reference economy. Table 2 summarizes the unique properties of the indices under five categories: (i) absolute/relative specialization (ii) order of ranking (iii) upper bound (iv) lower bound and (v) decomposability.

Table 2: Properties of Diversity Indices

\begin{tabular}{ccccc}
\hline Indices & $\begin{array}{c}\text { Absolute/ } \\
\text { Relative }\end{array}$ & $\begin{array}{c}\text { Reverse } \\
\text { Order }\end{array}$ & Upper Bound & Lower Bound \\
\hline HHI & Absolute & No & Unity & $1 / \mathrm{N}$ \\
AGV & Absolute & No & $(\mathrm{N}-1) / \mathrm{N}$ & Zero \\
QGV & Absolute & No & $(N-1)^{2} / N$ & Zero \\
ENT & Absolute & Yes & Natural log of $N$ & Zero \\
KRUG & Relative & No & $2(\mathrm{~N}-1) / \mathrm{N}$ & Zero \\
\hline
\end{tabular}

Notes: The reference level for absolute measures is the equal distribution of employment shares across all industries; relative specialization measures are based on the average economic structure of the jurisdictions in our sample. Reverse order refers to whether the index is increasing in diversity; four of the five indices exhibit this property, with the exception being the Entropy index.

The five indices discussed above are not without shortcomings. Gratton (1979) and Brown and Pheasant (1985) are of the opinion that both the absolute and relative specialization measures are arbitrary. For instance the absolute measures discount the fact that not only are certain industries expected to be naturally larger than others, such variations in size should be taken as an indication of a "vital, advanced economy" and not necessarily specialization (Palan, 2010; p. 7). Smith and Gibson (1988) express reservations on the emphasis placed on benchmarks; they argue that too much attention on diversification - to the detriment of specialization - could hurt a region's ability to exploit existing comparative advantages, which may in turn impact negatively on regional economic growth prospects. Palan provides further clarification on this argument through Conroy's (1975) advice that undue attention on a reference economy may imply that each region "possesses identical factor endowments and the same market area, which does not hold true in reality" (Palan, 2010; p. 7). Basing policy making on such notions of equalization in factor endowments and market area would be counterproductive.

Generally speaking, larger regional economies tend to be more economically diversified. Economists believe that metropolitan cities succeed because agglomeration economies raise productivity and economic growth (Porter, 1995; Glaeser, 2011). According to Slack, Bourne and Gertler (2003), innovation is the key to prosperity in the emerging global knowledge economy, and most innovation occurs in large metropolitan areas due to agglomeration economies. As such, our economic diversity indexes must be interpreted cautiously due to the positive relationship between economic size and diversity.

Wagner (2000) expresses his concerns on the static versus dynamic aspect of our diversity measures because, according to him, diversity is static measurement, while diversification and growth are dynamic concepts. Pede (2013) echoes this sentiment further by saying that the various indices are static measures that do not capture diversification effects. Pede (2013) says in the conclusion of his paper, "Given the appropriate sources of information, the study could be 
extended to examine the relationship between diversification and economic growth through a panel data approach. This work is left for future studies" (Pede, 2013; p. 124). This paper is one such study. Not only do we address diversity as changing levels of diversity through time (as modeled by O'Donoghue, 1999), we also employ the DPD methodology to overcome the endogeneity bias inherent in dynamic panel data. This is a major advance, and a further innovation of the Pede (2013) paper.

\subsection{Descriptive Statistics and Stylized Facts}

Table 3 displays the five most diverse and five least diverse US states, based on 2010 data. Table 4 does the same for all provinces in Canada. For the absolute indices of diversity, the results are quite clear. Among the group of the five most diverse states, Wyoming and North Dakota come first and second, respectively, with four and three appearances each. Iowa is the other state that appears thrice, albeit it trails North Dakota under the two indices where they both appear. Oklahoma, Arkansas and South Dakota all appear twice. For the five least diverse group, Nevada and New York are the top two candidates, with four appearances each. For Canada, Table 4 overwhelmingly confirms Saskatchewan as the most diverse province in Canada; Nova Scotia is the least diverse.

Table 3: Diversity Ranking for US Jurisdictions

Panel A: Five Most Diverse (most diverse first)

\begin{tabular}{|c|c|c|c|c|c|}
\hline & Entropy & $\begin{array}{l}\text { Absolute } \\
\text { Ogive }\end{array}$ & $\begin{array}{l}\text { Quadratic } \\
\text { Ogive }\end{array}$ & HHI & KRUG \\
\hline & $\begin{array}{l}\text { Wyoming } \\
\text { Alaska } \\
\text { North Dakota } \\
\text { Texas } \\
\text { Arkansas }\end{array}$ & $\begin{array}{l}\text { Rhode Island } \\
\text { Delaware } \\
\text { Wyoming } \\
\text { Iowa } \\
\text { Arkansas } \\
\end{array}$ & $\begin{array}{l}\text { Wyoming } \\
\text { North Dakota } \\
\text { Iowa } \\
\text { South Dakota } \\
\text { Oklahoma } \\
\end{array}$ & $\begin{array}{l}\text { Wyoming } \\
\text { North Dakota } \\
\text { Iowa } \\
\text { South Dakota } \\
\text { Oklahoma } \\
\end{array}$ & $\begin{array}{l}\text { Missouri } \\
\text { Georgia } \\
\text { Minnesota } \\
\text { California } \\
\text { Oregon } \\
\end{array}$ \\
\hline \multicolumn{6}{|c|}{ Panel B: Five Least Diverse (least diverse first) } \\
\hline & $\begin{array}{l}\text { Rhode Island } \\
\text { Massachusetts } \\
\text { Hawaii } \\
\text { New York } \\
\text { Nevada } \\
\end{array}$ & $\begin{array}{l}\text { Hawaii } \\
\text { New York } \\
\text { New Mexico } \\
\text { Maryland } \\
\text { Nevada } \\
\end{array}$ & $\begin{array}{l}\text { Massachusetts } \\
\text { Nevada } \\
\text { New York } \\
\text { Rhode Island } \\
\text { Florida } \\
\end{array}$ & $\begin{array}{l}\text { Massachusetts } \\
\text { Rhode Island } \\
\text { Nevada } \\
\text { New York } \\
\text { Maryland } \\
\end{array}$ & $\begin{array}{l}\text { Wyoming } \\
\text { Alaska } \\
\text { North Dakota } \\
\text { Mississippi } \\
\text { West Virginia }\end{array}$ \\
\hline $\begin{array}{l}\text { Max } \\
\text { Min }\end{array}$ & $\begin{array}{l}1.89 \\
1.58\end{array}$ & $\begin{array}{l}0.94 \\
0.67\end{array}$ & $\begin{array}{l}2.07 \\
0.83\end{array}$ & $\begin{array}{l}0.31 \\
0.18\end{array}$ & $\begin{array}{l}0.35 \\
0.04\end{array}$ \\
\hline
\end{tabular}

Clearly, the notion of equiproportional employment share or economic activity for each industry included in the construction of the indices is problematic. For instance, the linkages among the different sectors are not captured in the measures. Table 3 confirms this with states like Wyoming, Rhode Island and Alaska appearing in the top and bottom panels of the five most diverse and five least diverse economies in the US. The same is noticeable in Table 4 where Prince Edward Island and Quebec feature in both the top and bottom panels. Such diversity in results calls to question the assumption that ideal diversity represents equi-proportional 
employment levels. Most researchers in this field are in consensus; e.g. Conroy (1975) and Brown and Pheasant (1985) reject the equi-proportionality notion on the basis that it is arbitrary and without any theoretical justification. Brown and Pheasant (1985) conclude that the assumption makes the indices sensitive to the level of industry aggregation; Wagner and Deller (1998) point out the deficiency in the assumption of fixed industry sectors. As echoed by Brown and Pheasant (1985), we proceed with the ranking of the most diverse and least diverse jurisdictions with caution because our paper is based on 10 industry sectors, and the five indices are going to be sensitive to this level of industry aggregation.

Table 4: Diversity Ranking for Canadian Jurisdictions (from most to least diverse)

\begin{tabular}{|c|c|c|c|c|c|}
\hline & Entropy & Absolute Ogive & Quadratic Ogive & HHI & KRUG \\
\hline & Saskatchewan & Saskatchewan & Saskatchewan & Saskatchewan & Ontario \\
\hline & Alberta & Alberta & Alberta & Alberta & Manitoba \\
\hline & Manitoba & Manitoba & Manitoba & Prince Edward & Quebec \\
\hline & New Brunswick & New Brunswick & Prince Edward & Manitoba & Brit. Columbia \\
\hline & Ontario & Ontario & New Brunswick & New Brunswick & New Brunswick \\
\hline & Quebec & Prince Edward & Newfoundland & Newfoundland & Nova Scotia \\
\hline & Brit. Columbia & Brit. Columbia & Ontario & Ontario & Alberta \\
\hline & Newfoundland & Quebec & Quebec & Quebec & Newfoundland \\
\hline & Prince Edward & Newfoundland & Brit. Columbia & Brit. Columbia & Saskatchewan \\
\hline & Nova Scotia & Nova Scotia & Nova Scotia & Nova Scotia & Prince Edward \\
\hline Max & 1.94 & 0.86 & 1.73 & 0.27 & 0.21 \\
\hline Min & 1.68 & 0.65 & 1.12 & 0.21 & 0.06 \\
\hline
\end{tabular}

The conclusion we come to is that the absolute indices of diversity are not that different from each other. For instance, the HHI can theoretically take on values between 0.1 and 1, but we only get between 0.18 and 0.31 in the US case, which is quite a small range. The relatively highly aggregated nature of our data does not allow for much diversity to be picked up. To attempt to move to lower levels of disaggregation is to risk the deletion, from our sample, of data points that are suppressed to meet confidentiality requirements.

In Table 5, we examine the correlation matrix for all five measures. As discussed above, the Entropy, HHI and both versions of the Ogive indices belong to the group of absolute specialization measures; KSI is the only relative specialization measure among all five indices. As might be expected (also from Tables 3 and 4), the four absolute measures are all highly correlated with each other (note the entropy index is the only index that is decreasing in diversity, hence the negative correlations with the other indices). 
Table 5: Correlation Matrix for Diversity Indices

\begin{tabular}{lccccc}
\hline Indices & ENT & AGV & QGV & HHI & KRUG \\
\hline ENT & 1.00 & & & & \\
AGV & -0.64 & 1.00 & & & \\
QGV & -0.85 & 0.66 & 1.00 & & \\
HHI & -0.81 & 0.65 & 0.99 & 1.00 & \\
KRUG & 0.14 & 0.11 & -0.12 & -0.12 & 1.00 \\
\hline
\end{tabular}

Finally, we examine our sole relative specialization measure, the KSI. In stark contrast to the other indicators, the KSI is only weakly correlated with the other measures of specialization. This can also be established from Tables 3 and 4, where it is clear that the rankings of jurisdictions are very different using the KSI instead of the other diversity measures. We can establish the following: (i) because of the high correlations between the absolute measures of diversity, we should expect empirical studies using these indices to yield similar results; (ii) the absolute and relative specialization indices measure different concepts of specialization (or diversity), and hence we should expect different results when comparing between the different groups of indices.

In addition, Palan (2010) notes:

A general problem of specialization indices is that they are only able to give a very aggregate picture and thus convey only a limited understanding of the development of the economic structure of a country, since they give no information about the underlying developments, i.e. in which industries countries are specializing (p. 31).

Table 6 shows the mining share of GDP across jurisdictions. Wyoming and Alaska in the US, and Newfoundland and Alberta in Canada, are the two jurisdictions with the largest contribution of mining to GDP in both countries. In contrast, the economies of Delaware, Prince Edward Island, Ontario and Quebec show only minimal mining activity, with sectoral contribution of less than $0.5 \%$ in each of the four jurisdictions ${ }^{3}$. This will be very important in the next section when we conduct a formal test of the dependence of per capita output on the mining sector.

Table 6: Mining Share of GDP (2010)

\begin{tabular}{lclc}
\hline Panel A: US States & & & \\
\hline State & $\begin{array}{c}\text { Mining Share of } \\
\text { GDP }(\boldsymbol{\%})\end{array}$ & State & $\begin{array}{c}\text { Mining Share of } \\
\text { GDP }(\boldsymbol{\%})\end{array}$ \\
\hline Top Five & & Bottom Five & \\
Wyoming & 32.9 & Delaware & 0.2 \\
Alaska & 25.5 & Maine & 1.6 \\
West Virginia & 12.9 & Massachusetts & 3.3 \\
Oklahoma & 10.9 & New Jersey & 4.4 \\
\hline
\end{tabular}

${ }^{3}$ Obviously, the mining sector may be large in absolute terms, even when the percentage contribution to state GDP is small. 


\begin{tabular}{lclc}
\hline Louisiana & 9.0 & Rhode Island & 5.5 \\
\hline Panel B: Canadian Provinces & $\begin{array}{c}\text { Mining Share of } \\
\text { GDP }(\boldsymbol{\%})\end{array}$ & Province & $\begin{array}{c}\text { Mining Share of } \\
\text { GDP }(\%)\end{array}$ \\
\hline Province & & Bottom Five & \\
\hline Top Five & 27.3 & Prince Edward & 0.1 \\
Newfoundland & 19.4 & Ontario & 0.4 \\
Alberta & 13.3 & Quebec & 0.4 \\
Saskatchewan & 3.0 & New Brunswick & 1.3 \\
British Columbia & 1.7 & Nova Scotia & 1.7 \\
Manitoba & & & \\
\hline
\end{tabular}

\subsection{Model Specification}

The contribution of this paper is to identify the mediating effect of economic diversity on the effect of natural resources on economic growth within the US and Canada. In particular, we examine whether or not the resource curse is, on average, more or less prevalent in jurisdictions with more diversified economies than in those with less diversified economies. By focusing on these two countries with a reasonably unified culture, geography and institutional arrangements, we hope to avoid some of the pitfalls of using cross-country data. Papers which use crosscountry data potentially suffer from biases generated by the heterogeneity of their samples since unobserved factors - such as culture, geography or climate - could affect the intensity of the curse through different channels. Not just that, the effect of natural resources on growth might depend on country-specific structural factors such as the composition of the economy.

Focusing on US and Canadian sub-national jurisdictions provides the added advantage of examining 60 jurisdictions with significant autonomy over institutional, economic and governance issues such as diversification, human capital and regulatory policy. The resourcediversity-growth framework is presented in Equation (8):

Where:

$$
\begin{gathered}
\mathrm{RGDP}_{t}=\alpha_{0}+\alpha_{1} \ln \left(R G D P_{t-1}\right)+\alpha_{2}\left(D I V_{t}\right)+\alpha_{3}\left(N R S_{t}\right)+\alpha_{4}\left(D I V_{t} \cdot N R S_{t}\right) \\
+X_{i}+\eta_{t}+\mu_{t}
\end{gathered}
$$

$$
\begin{array}{ll}
\ln \left(R G D P_{t}\right) & =\log \text { of real per capita GDP } \\
\ln \left(R G D P_{t-1}\right) & =\log \text { of lagged real per capita GDP } \\
N R S & =\text { Natural resource measure } \\
D I V & =\text { Diversity measure } \\
E D U & =\text { Human capital stock } \\
C A P & =\text { Physical capital stock } \\
X, \eta & =\text { A set of year-specific and jurisdiction-specific effects } \\
\mu & =\text { Random error term }
\end{array}
$$

The random error is a normally distributed idiosyncratic error term, with mean 0 and variance $\sigma_{\varepsilon}^{2}$, that captures all other omitted effects on real GDP per capita and is assumed to be wellbehaved. 
We revisit the hypothesis that the resource curse does exist; but economic diversity can help to abate it. Partially differentiating Equation (8) with respect to the natural resource measure, we capture the partial impact of an increase in natural resources on growth for the diversity channel in Equation (9):

$$
\frac{\partial R G D P}{\partial N R S}=\alpha_{3}+\alpha_{4} * D I V
$$

The resource curse hypothesis is denoted by $\alpha_{3}<0$; the notion that a highly diversified regional economy can alleviate the curse is captured by $\alpha_{4}>0$. We expect regions to show no sign of the curse (i.e. $\alpha_{3}+\alpha_{4} * D I V \geq 0$ ) when $D I V$ is greater than the threshold $-\alpha_{3} / \alpha_{4}$. The implication of Equation (9) is that we expect the marginal effect of resources on economic growth to vary according to the extent of economic diversity. As such we are interested in examining the sum of the direct effect of resources on growth on the one hand and its indirect effect through the extent of economic diversity on the other hand. As stated earlier, we adopt the GMM strategy to address potential endogeneity issues in our estimation. In addition, we include the lagged value of the dependent variable, our standard control variables and regional dummies to account for unobserved heterogeneity.

\section{$4 \quad$ Estimation Results}

We present FEM and two-step system GMM (SYST-GMM) estimation results for the resourcediversity-growth nexus. Results for each of our five indicators are considered; this allows us to check the robustness of our findings to alternative definitions of diversity.

\subsection{FEM Estimation Results}

Results of the classical OLS estimator come out with R-squared values between $59.5 \%$ and 90.2\%; the former for the AGV and the latter for KRUG. The lagged dependent variable ends up with statistically significant coefficients (at 1\%) for all five models. Our focus is on the FEM and DPD results, hence we do not further discuss the OLS results (which are available from the authors upon request).

Controlling for jurisdictional fixed effects is a way to capture unobserved and persistent regional variations that influence long-run per capita income. We present our FEM results in Table 7. The coefficient on $\mathrm{Y}_{\mathrm{it}-1}$ is positive and statistically significant at the $1 \%$ level in all cases. The OLS estimator produces a higher absolute coefficient value for $Y_{i t-1}$ compared to the FEM in all five specifications. This finding is in line with the propositions by Nickel (1981), Roodman (2009) and Bond (2002), and is indicative of the bias in the OLS estimates.

In terms of predictive ability, the FEM does much better than the OLS. With positive and statistically significant coefficients, four specifications refute the resource curse notion; only in the Entropy model is it not statistically significant. In the same vein, the HHI, QGV and ENT models support the notion that diversity promotes economic growth. Only the KRUG model, through a negative interactive coefficient, provides a clear prediction on the role of economic diversity as a transmission channel of the curse, indicating that greater economic diversity has a negative impact on per capita income, the more natural resource-dependent is the jurisdiction.

\footnotetext{
${ }^{4}$ Recall the Entropy index works in reverse order.
} 
Our control variables (capital stock and educational attainment) under all five models produce positive and statistically significant coefficients, in support of the predictions in the growth empirics literature that per capita incomes are positively associated with both variables.

Table 7: FEM Estimation Results (Resource-Diversity-Growth Nexus) (dependent variable: $\ln (\boldsymbol{R} G D P)$.

[1]

\begin{tabular}{lccccc} 
& & Absolute & Quadratic & & \\
Diversity Index & Herfindahl & Ogive & Ogive & Entropy & Krugman \\
\hline Log of lagged RGDP & $0.328^{* * *}$ & $0.518 * * *$ & $0.272 * * *$ & $0.390 * * *$ & $0.532 * * *$ \\
& {$[0.074]$} & {$[0.040]$} & {$[0.061]$} & {$[0.051]$} & {$[0.032]$} \\
Diversity & $0.689^{* * *}$ & 0.379 & $0.465^{* * *}$ & $-1.474 * * *$ & -0.041 \\
& {$[0.194]$} & {$[0.427]$} & {$[0.066]$} & {$[0.465]$} & {$[0.044]$} \\
Natural Resources & $0.084 *$ & $0.092^{* * *}$ & $0.058^{* *}$ & 0.070 & $0.069 * * *$ \\
& {$[0.043]$} & {$[0.027]$} & {$[0.025]$} & {$[0.043]$} & {$[0.022]$} \\
Diversity x natural & 0.010 & 0.039 & 0.011 & 0.011 & $-0.331 *$ \\
resources & {$[0.020]$} & {$[0.064]$} & {$[0.011]$} & {$[0.061]$} & {$[0.181]$} \\
Capital stock & $0.301 * * *$ & $0.224 * * *$ & $0.305 * * *$ & $0.284 * * *$ & $0.238^{* * *}$ \\
& {$[0.074]$} & {$[0.070]$} & {$[0.081]$} & {$[0.077]$} & {$[0.071]$} \\
Educational attainment & $0.462 * * *$ & $0.607 * * *$ & $0.466 * * *$ & $0.537 * * *$ & $0.586 * * *$ \\
& {$[0.077]$} & {$[0.057]$} & {$[0.087]$} & {$[0.066]$} & {$[0.063]$} \\
\hline Year fixed effects & Yes & Yes & Yes & Yes & Yes \\
Jurisdictions & 60 & 60 & 60 & 60 & 60 \\
Observations & 360 & 360 & 360 & 360 & 360 \\
R-Squared & 0.892 & 0.870 & 0.901 & 0.891 & 0.87 \\
\hline
\end{tabular}

Note: Figures in parentheses are robust standard errors. * significant at $10 \%$; **significant at $5 \%$; ***significant at $1 \%$. The natural resources variable is constructed as the mining share of GDP; all five diversity measures are constructed using employment distribution for the 10 chosen sectors.

\subsection{GMM Estimation Results}

Given the importance attached to the dichotomy between diversity and diversification from a static-dynamic point of view in the literature (e.g. Siegel, Johnson and Alwang, 1993a, 1993b, 1995b; Malizia and Ke, 1993; Wagner and Deller, 1998; and Wagner, 2000), the need for a dynamic specification as a way to set the record straight cannot be overemphasized. This is especially important given the sentiment of diversity researchers (e.g. Wagner, 2000) on the need to clearly distinguish between diversity and diversification when testing the link between diversity and growth. As pointed out earlier, our paper is the first to model diversity using the GMM technique under a Canada-US sub-national framework. Given O'Donoghue's (1999) differentiation $^{5}$ of diversification from diversity, we employ the two-step system GMM method as a way of advancing the work of Pede (2013).

\footnotetext{
${ }^{5}$ O’Donoghue (1999) defines diversification as changing levels of diversity through time.
} 
The equation to be estimated (Equation (8)) cannot be consistently estimated using simple OLS or static panel methods due to endogeneity between key model variables. The system GMM helps overcome endogeneity by generating internal instruments. As discussed above, one of the major arguments against the resource curse hypothesis is the choice of natural resource proxy used by pioneers: the ratio of resource exports to GDP. First, this variable is seen more as an indicator of resource intensity (or resource dependence) than as an indicator of resource abundance. Second, it suffers from endogeneity because the denominator in the ratio (i.e. GDP) captures the extent of activity in each of the other economic sectors. Clarida and Findlay (1992) clarify this further by stating that the denominator also measures the comparative advantage in non-resource sectors, which to a large extent, is determined by government choices that ultimately impact economic growth. To avoid such pitfalls, we explicitly model our natural resource proxy (mining as a share of GDP) as an endogenous variable. As part of our robustness checks, we will also use mining as a share of employment as a proxy for natural resources.

One major conclusion reached under the review of our diversity measures is that all five indices are arbitrary. We therefore model our diversity measures as endogenous variables. In addition, Human capital and investment are traditionally seen as growth-promoting (Solow, 1956; Mankiw et al, 1992). For instance, when we control for other things, we would expect higher economic outcomes for jurisdictions like Ontario and Massachusetts (with high scores on our educational attainment scale), compared to Newfoundland and West Virginia, which lag behind others. The same reasoning goes for physical capital stock. Both variables suffer from endogeneity. Hence, these variables are modeled with GMM-style instruments.

The tables below present the results of the two-step system GMM estimation under all five diversity measures. With all GMM-style instruments included, 152 instruments are generated in each specification. The respective p-values of the Sargan and Hansen tests are 0.000 and 1.000, while the Arellano-Bond AR(2) test p-value is 0.0001 in each case. Clearly, this does not pass the Sargan test of overidentifying restrictions, and is indicative of an overfitting problem. Likewise, the value of 1.000 on the Hansen test suggests there is problem with the validity of the instruments used. The last of our tests, the $\mathrm{AR}(2)$ in disturbances, also rejects the null hypothesis; it therefore does not support the validity of the instruments used in all five specifications.

We deal with the issues of under-identification, instrument proliferation and weak instruments once-and-for-all and present only the results of the final and well-behaved specifications. We perform a series of specification checks, including reducing lag lengths starting from the second to the sixth (that is, lags fewer than the mentioned number are not included in the set of instruments). A trade-off always emerges: models that perform well on the Sargan and Hansen tests often do badly on either the AR(2) or coefficient statistical significance. From the second to the sixth lags, models with the sixth lags included perform best, followed by the fourth lags. With the fourth lags, 40 instruments are generated; only 16 instruments for the sixth lags. We report the results using the sixth lags in Table 8.

Across all models, with only 16 instruments, the Sargan and Hansen test p-values are quite far away from zero, and not close to 1.0. The AR(2) test gives all models a clean bill of health from 
disturbances. The coefficient estimate of lagged real per capita GDP is sensitive to the choice of lag length, but remains statistically significant in all models. As mentioned above, the main downside is the loss of predictive power from the well-behaved model, since many coefficients are not statistically significant. This may be a sign that we have over-pruned the instrument set. However, the alternative of increasing the instrument count does not seem to be a way out, given the performance of the diagnostic tests under instrument proliferation. In all, our results show that the SYST-GMM estimator handles well the problem of endogenous regressors by generating internal instruments from their lagged values. This strategy also augurs well for our staticdynamic and diversity-diversification debates.

Table 8: Two-Step System GMM Results (Resource-Diversity-Growth Nexus) (dependent variable: $\ln (R G D P)$.

\begin{tabular}{|c|c|c|c|c|c|}
\hline Diversity Index Used & $\begin{array}{l}\quad[1] \\
\text { Herfindahl } \\
\end{array}$ & $\begin{array}{c}{[2]} \\
\text { Absolute } \\
\text { Ogive } \\
\end{array}$ & $\begin{array}{c}{[3]} \\
\text { Quadratic } \\
\text { Ogive }\end{array}$ & Entropy & Krugman \\
\hline Log of lagged RGDP & $\begin{array}{l}0.630 * * \\
{[0.260]}\end{array}$ & $\begin{array}{c}0.943 * * * \\
{[0.322]}\end{array}$ & $\begin{array}{c}0.448 * * \\
{[0.031]}\end{array}$ & $\begin{array}{c}0.720 * * * \\
{[0.252]}\end{array}$ & $\begin{array}{l}0.700 * * \\
{[0.308]}\end{array}$ \\
\hline Diversity & $\begin{array}{c}1.275 \\
{[2.120]}\end{array}$ & $\begin{array}{c}0.055 \\
{[1.735]}\end{array}$ & $\begin{array}{l}1.382 * \\
{[0.803]}\end{array}$ & $\begin{array}{c}2.482 \\
{[5.376]}\end{array}$ & $\begin{array}{l}-0.135 \\
{[0.395]}\end{array}$ \\
\hline Natural resources & $\begin{array}{c}0.070 \\
{[0.469]}\end{array}$ & $\begin{array}{l}-0.019 \\
{[0.091]}\end{array}$ & $\begin{array}{c}0.070 \\
{[0.092]}\end{array}$ & $\begin{array}{l}-0.379 \\
{[0.330]}\end{array}$ & $\begin{array}{l}-0.073 \\
{[0.060]}\end{array}$ \\
\hline $\begin{array}{l}\text { Diversity x natural } \\
\text { resources }\end{array}$ & $\begin{array}{c}0.007 \\
{[0.290]}\end{array}$ & $\begin{array}{l}-0.143 \\
{[0.367]}\end{array}$ & $\begin{array}{c}0.073 \\
{[0.157]}\end{array}$ & $\begin{array}{c}0.685 \\
{[0.512]}\end{array}$ & $\begin{array}{l}-0.980 \\
{[0.953]}\end{array}$ \\
\hline Capital stock & $\begin{array}{l}-0.264 \\
{[0.338]}\end{array}$ & $\begin{array}{l}-0.335 \\
{[0.286]}\end{array}$ & $\begin{array}{c}-0.474 * * \\
{[0.221]}\end{array}$ & $\begin{array}{l}-0.031 \\
{[0.227]}\end{array}$ & $\begin{array}{l}-0.199 \\
{[0.497]}\end{array}$ \\
\hline Educational attainment & $\begin{array}{l}-0.134 \\
{[0.170]} \\
\end{array}$ & $\begin{array}{r}-0.439 \\
{[0.378]} \\
\end{array}$ & $\begin{array}{l}-0.076 \\
{[0.240]} \\
\end{array}$ & $\begin{array}{l}-0.107 \\
{[0.454]} \\
\end{array}$ & $\begin{array}{l}-0.297 \\
{[0.619]} \\
\end{array}$ \\
\hline Year fixed effects & Yes & Yes & Yes & Yes & Yes \\
\hline Observations & 360 & 360 & 360 & 360 & 360 \\
\hline Jurisdictions & 60 & 60 & 60 & 60 & 60 \\
\hline Number of instruments & 16 & 16 & 16 & 16 & 16 \\
\hline Number of lags used & 6 & 6 & 6 & 6 & 6 \\
\hline Sargan Test ( $\mathrm{p}$ value) & 0.003 & 0.056 & 0.249 & 0.266 & 0.821 \\
\hline Hansen Test ( $\mathrm{p}$ value) & 0.003 & 0.020 & 0.264 & 0.016 & 0.672 \\
\hline AB AR(1) (p-value) & 0.358 & 0.430 & 0.007 & 0.254 & 0.561 \\
\hline AB AR(2) (p-value) & 0.726 & 0.157 & 0.077 & 0.314 & 0.019 \\
\hline
\end{tabular}

Notes: Figures in parentheses are robust standard errors. * significant at 10\%; **significant at 5\%; ***significant at 1\%. Data are for three-year intervals between 1987 and 2010. All estimations based on the Windmeijer's (2005) finite sample correction to the standard errors. The proxy for natural resources is mining as a share of GDP; our five diversity measures are based on the employment shares in the 10 industry sectors included in this chapter. Interaction term is the product of the interaction between natural resources and diversity.

The coefficient for $Y_{i t-1}$ is positive and statistically significant in all cases; this confirms that the GMM estimators generally work as expected in estimating the coefficient on the lagged dependent variable in the presence of endogenous explanatory variables. The results indicate convergence of per capita incomes. On the other hand, capital stock and educational attainment 
are almost always statistically insignificant in all models, suggesting that the effect of capital and education on per capita GDP is absorbed by the other variables in the model.

Except for the AGV specification, the two-step GMM estimator passes the "candidate consensus estimator" test for the other four indices, with coefficient values lying in-between the OLS and FEM estimates. With a positive and economically significant coefficient, our QGV specification lends support to the growth-promoting effect of economic diversity. Therefore, there is some evidence using GMM that economic diversity is associated with increased levels of per capita income. Hence, our contribution to the diversity-growth debate is that economic diversification may be a strategy that can help mitigate unforeseen problems in the event of structural changes in a regional economy.

This result is important for the following reasons. First, we join other researchers who have established a positive direct relationship for the diversity-growth nexus (e.g. Hackbart and Anderson, 1975; Dissart, 2003; and Pede, 2013). Second, the GMM technique employed addresses the issue of endogeneity which is a major limitation that qualifies most results in this area. Finally, the use of dynamic panel techniques is a major advance because it helps to capture structural change and industrial transformation in regional economies. As pointed out earlier, Wagner and Pede express their concerns that diversity is a static measurement, while diversification and growth are dynamic concepts. They therefore conclude that it would be difficult for static measures to capture the changing structures of regional economies - the socalled diversification effects. Since we use a dynamic panel data model, our paper provides better insights on the static-dynamic nuances in the analysis of economic diversity, improving on the work of O'Donoghue (1999) and Pede.

Because the coefficients on natural resources are not statistically significant, the GMM results indicate that there is no evidence of the resource curse. Neither do we find a significant interaction effect between diversity and resources. We therefore rely on the results from the FEM model of the Krugman index (column [5] of Table 7) to make inferences on the impact of diversity on the resource curse. The marginal effect of an increase in natural resource abundance on growth is:

$$
\frac{\partial R G D P}{\partial N R S}=\alpha_{3}+\alpha_{4} * D I V=0.069-0.331 * D I V
$$

This implies that the diversity threshold for not having the resource curse is $-\alpha_{3} / \alpha_{4}=$ $-(0.069 /-0.331)=0.209$. Above this threshold, the marginal contribution of natural resources to per capita income is lower for a more diversified regional economy than a less diversified one, while the reverse is true below this threshold. That is, jurisdictions with a KRUG value greater than 0.209 will suffer from the natural resource curse, while those below it will not. Since the Krugman Index ranges from 0.04 to 0.35 in the sample (see Tables 3 and 4), the turning point occurs within our sample, and is an economically meaningful result. But, whilst this result appears to contradict our prior (that more diverse jurisdictions would be insulated from the resource curse), there may in fact be a simple explanation for this. A jurisdiction which is abundant in natural resources, yet does not fully exploit these resources because they have overdiversified, may be expected to have lower per capita incomes than otherwise. 


\subsection{Sensitivity Analysis}

As discussed earlier, diversity is commonly modelled using employment distribution across industry sectors. Palan (2010) believes the use of employment distribution in the construction of diversity indexes may result in productivity biases. We therefore believe GDP is the next most preferred alternative variable that can help gauge the distribution of sectoral economic activity. We apply our two-step system GMM estimation technique with all diversity indexes constructed based on GDP distribution across our 10 industry sectors. Results are presented in Table 9.

Overall, the coefficients on the lagged dependent variable are broadly comparable for all five indices, ranging from 0.555 to 0.924 , compared to 0.448 to 0.943 under the employment-based measures. The $p$ values of the Hansen and Sargan tests equally suggest that our choice of internal instrumental variables are valid for the SYST-GMM. The diagnostic tests behave well and produce dependable results for the most part only when the instrument count is reduced substantially. We therefore end up with seemingly too few instruments in some cases. This is a trade-off we have to accept to avoid the problem of too many instruments.

Table 9: Alternative Measures of Diversity (dependent variable: $\ln (R G D P)$.

\begin{tabular}{|c|c|c|c|c|c|}
\hline Diversity Index Used & $\begin{array}{l}\text { [1] } \\
\text { Herfindahl }\end{array}$ & $\begin{array}{c}{[2]} \\
\text { Absolute } \\
\text { Ogive } \\
\end{array}$ & $\begin{array}{c}{[3]} \\
\text { Quadratic } \\
\text { Ogive } \\
\end{array}$ & Entropy & Krugman \\
\hline Lagged log GDP & $\begin{array}{c}0.924 * * * \\
{[0.257]}\end{array}$ & $\begin{array}{c}0.633 * * \\
{[0.259]}\end{array}$ & $\begin{array}{c}0.718 * * * \\
{[0.266]}\end{array}$ & $\begin{array}{c}0.755 * * * \\
{[0.128]}\end{array}$ & $\begin{array}{c}0.555^{* *} \\
{[0.241]}\end{array}$ \\
\hline Diversity & $\begin{array}{l}-1.567 \\
{[1.229]}\end{array}$ & $\begin{array}{l}1.200^{*} \\
{[0.615]}\end{array}$ & $\begin{array}{l}-0.011 \\
{[0.717]}\end{array}$ & $\begin{array}{c}-2.703 * * \\
{[1.334]}\end{array}$ & $\begin{array}{c}0.549 \\
{[0.348]}\end{array}$ \\
\hline Natural resources & $\begin{array}{l}-0.097 \\
{[0.384]}\end{array}$ & $\begin{array}{c}0.036 \\
{[0.050]}\end{array}$ & $\begin{array}{l}-0.014 \\
{[0.070]}\end{array}$ & $\begin{array}{c}0.068 \\
{[0.109]}\end{array}$ & $\begin{array}{c}0.072 \\
{[0.113]}\end{array}$ \\
\hline $\begin{array}{l}\text { Diversity x natural } \\
\text { resources }\end{array}$ & $\begin{array}{c}-0.004 \\
{[0.218]}\end{array}$ & $\begin{array}{l}-0.026 \\
{[0.069]}\end{array}$ & $\begin{array}{l}-0.056 \\
{[0.075]}\end{array}$ & $\begin{array}{l}-0.047 \\
{[0.157]}\end{array}$ & $\begin{array}{c}0.072 \\
{[0.071]}\end{array}$ \\
\hline Capital stock & $\begin{array}{c}-1.040 * * \\
{[0.431]}\end{array}$ & $\begin{array}{c}0.256 \\
{[0.276]}\end{array}$ & $\begin{array}{l}-0.130 \\
{[0.412]}\end{array}$ & $\begin{array}{l}-0.075 \\
{[0.272]}\end{array}$ & $\begin{array}{l}-0.016 \\
{[0.222]}\end{array}$ \\
\hline Educational attainment & $\begin{array}{c}-1.236 * * \\
{[0.527]} \\
\end{array}$ & $\begin{array}{c}0.028 \\
{[0.475]}\end{array}$ & $\begin{array}{c}-0.355 \\
{[0.559]}\end{array}$ & $\begin{array}{c}-0.328 \\
{[0.216]}\end{array}$ & $\begin{array}{c}0.153 \\
{[0.491]}\end{array}$ \\
\hline Year fixed effects & Yes & Yes & Yes & Yes & Yes \\
\hline Observations & 360 & 360 & 360 & 360 & 360 \\
\hline Jurisdictions & 60 & 60 & 60 & 60 & 60 \\
\hline Number of instruments & 16 & 16 & 16 & 16 & 16 \\
\hline Number of lags used & 6 & 6 & 6 & 6 & 6 \\
\hline Sargan Test ( $p$ value) & 0.244 & 0.188 & 0.013 & 0.196 & 0.426 \\
\hline Hansen Test ( $p$ value) & 0.270 & 0.479 & 0.029 & 0.058 & 0.245 \\
\hline AB AR(1) (p-value) & 0.074 & 0.155 & 0.132 & 0.172 & 0.416 \\
\hline $\operatorname{AB} \operatorname{AR}(2)(p$-value $)$ & 0.886 & 0.082 & 0.098 & 0.011 & 0.000 \\
\hline
\end{tabular}

Note: Figures in parentheses are robust standard errors. * significant at 10\%; **significant at 5\%; ***significant at 1\%. Data are for three-year intervals between 1987 and 2010. All estimations based on the Windmeijer's (2005) finite sample correction to the standard errors. The proxy for natural resources is mining as a share of GDP; our five diversity measures are based on the GDP shares in the 10 industry sectors included in this chapter. Interaction term is the product of the interaction between natural resources and diversity. 
Similar to our finding under the employment-based measures, we conclude that economic diversity has a growth-promoting effect. Again, this conclusion is a weighty one because it comes without any qualification related to endogeneity or the static-dynamic caveat. Again, however, the coefficients on the natural resource measure and the interaction term are not statistically significant. We therefore do not have evidence on the possible harmful effect of resources on growth. Neither are we able to establish diversity as medium of transmission of the effect of natural resources on growth. We also again reach the conclusion that the five diversity indices are arbitrary and sensitive to the level of industry aggregation used because the assumption of equi-proportionality lacks any theoretical justification ${ }^{6}$.

\section{Summary and Conclusions}

In this paper, we bring together two closely related strands of literature. On the one hand, economic diversity is widely believed to be a potent tool policymakers use to achieve their stability and economic growth objectives. However, explaining the specific reasons why diversification helps some economies to succeed where others fail remains a mirage. To further complicate things, most empirical investigations of the relationship between economic growth and diversity provide inconclusive evidence. On the other hand, the literature on the resource curse suggests that an indirect consequence of natural wealth is the resource curse; however, much of the contemporary evidence on the curse conclude that the transmission mechanism of the curse is more important.

In this paper, we propose a dynamic panel method of regressions as a solution to the resourcesdiversification-growth question. We estimate a conditional growth model to explain real per capita income at the US state and Canadian provincial level as a function of natural resources and five employment-based diversity indexes. An interaction term between natural resources and diversity helps to identify whether diversification can influence or reduce the effects of the resource curse.

The QGV (quadratic ogive) model supports the growth-promoting stance of economic diversity, and we conclude that economic diversity is associated with increased levels of economic growth. The use of dynamic panel techniques also helps resolve the uncertainty related to the diversification effects. We join other empirical researchers who find evidence for a positive direct relationship for the diversity-growth nexus (e.g. Hackbart and Anderson, 1975; Dissart, 2003; and Pede, 2013). Due to statistically insignificant coefficients, the GMM framework does not provide us with evidence on the resource curse, and on the interactive effect of diversity on resources. The FEM using the Krugman Index of diversity, which yields statistically and economically significant coefficients, captures the partial impact of an increase in natural resources on growth through the diversity transmission channel. The required diversity threshold for not having the resource curse is given as 0.209. Above this threshold, the marginal

\footnotetext{
${ }^{6}$ An additional sensitivity analysis we perform is to assume that the diversity indices are strictly exogenous, and are instrumented in the GMM models with IV-style instruments. The results are very similar to those reported above, and are omitted for brevity.
} 
contribution of natural resources to economic growth is lower for a relatively more diversified regional economy than a less diversified one. We draw a major policy conclusion: that regional economies which are too diversified are the ones in which resource abundance is harmful to per capita incomes. These results are robust to measures of diversity based on GDP, and to the assumption that the diversity indices are strictly exogenous. We conclude that our approach may also help shed light on the static versus dynamic effects of diversification, and diversity versus diversification debates.

\section{References}

1. Ahmadov, A. (2012). Political Determinants of Economic Diversification in Natural Resource-Rich Developing Countries. Preliminary Draft

2. Attaran, M. (1986). Industrial Diversity and Economic Performance in US Areas. Annals of Regional Science, 20(2): 44-54

3. Attaran, M. and M. Zwick (1987). The Effect of Industrial Diversification on Employment and Income: A Case Study. Quarterly Review of Economics and Business, $27: 38-54$

4. Auty, R. and R. Mikesell (1998). Sustainable Development in Mineral Economies. Oxford: Clarendon Press.

5. Barro, R. and J. Lee (2012). A New Data Set of Educational Attainment in the World, 1950-2010. NBER Working Paper Series No. 15902

6. Beine, M. and S. Coulombe (2007). Economic Integration and Regional Industrial Specialization: Evidence from the Canadian-US FTA Experience. Journal of Economic Geography, 7(1): 93-111.

7. Béland, L. and R. Tiagi (2009). Economic Freedom and the "Resource Curse": An Empirical Analysis. Studies in Mining Policy, Fraser Institute.

8. Bishop, P. and P. Gripaios (2010). Spatial Externalities, Relatedness and Sector Employment Growth in Great Britain. Regional Studies, 44(4): 443-54

9. Bond, S. (2002). Dynamic Panel Data Models: A Guide to Micro Data Methods and Practice. Working Paper CWP09/02, Cemmap, Institute for Fiscal Studies

10. Boyce, J. and J. Emery (2011). Is a Negative Correlation between Resource Abundance and Growth Sufficient Evidence that there is a 'Resource Curse'? Resources Policy, 36(1): 1-13.

11. Brown, D. and J. Pheasant (1985). A Sharpe Portfolio Approach to Regional Economic Analysis. Journal of Regional Science, 25:51-63 
12. Bulte, E., R. Damania and T. Deacon (2005). Resource Intensity, Institutions, and Development. World Development, 33(7): 1029-44

13. Clarida, R. and R. Findlay (1992). Government, Trade, and Comparative Advantage. American Economic Review, 82(2): 122-7.

14. Collier, P. and A. Venables (2007). Rethinking Trade Preferences: How Africa Can Diversify its Exports. The World Economy, 30(8):1326-45

15. Collier, P. and B. Goderis (2007). Commodity Prices, Growth, and the Natural Resource Curse: Reconciling a Conundrum. Centre for the Study of African Economies, Working Paper No. 2007-15

16. Conroy, M. (1975). The Concept and Measurement of Regional Industrial Diversification. Southern Economic Journal, 41: 492-505

17. Corden, W. and Neary, J. (1982). Booming Sector and De-industralisation in a Small Open Economy. The Economic Journal, 92 (368): 825-48

18. Davis, D. (1998). The Home Market Effect, Trade, and Industrial Structure. American Economic Review, 88(5): 1264-76

19. Ding, N. and B. Field (2005). Natural Resource Abundance and Economic Growth. Land Economics, 81(4): 496-502

20. Dissart, J. (2003). Regional Economic Diversity and Regional Economic Stability: Research Results and Agenda. International Regional Science Review, 26(4): 423-46

21. Ezcurra R., P. Pascual and M. Rapun (2006). Regional Specialization in the European Union. Regional Studies 40: 601-616

22. Feldman, M. and D. Audretsch (1999). Innovation in Cities: Science-Based Diversity, Specialization and Localized Competition. European Economic Review, 43: 409-29

23. Frenken, K., F. Van Oort, and T. Verburg (2007). Related Variety, Unrelated Variety and Regional Economic Growth. Regional Studies, 41:685-97

24. Garrison, C. and A. Paulson (1973). An Entropy Measure of the Geographic Concentration of Economic Activity. Economic Geography, 49(4): 319-24

25. Gelb, A. (2010). Economic Diversification in Resource Rich Countries. Seminar by the Central Bank of Algeria and the IMF Institute in Algiers, on 4-5 November 2010

26. Gelb, A. and S. Grasmann (2010). How Should Oil Exporters Spend their Rents? Center for Global Development, Working Paper 221 
27. Glaeser, E. (2011). Triumph of the City: How Our Greatest Invention Makes Us Richer, Smarter, Greener, Healthier, and Happier”, New York: Penguin Press

28. Gratton, C. (1979). Industrial Diversification in New Towns. Urban Studies, 16:157-64

29. Gylfason, T. (2001). Natural Resources and Economic Growth: What is the Connection? Center for Economic Studies \& Ifo Institute for Economic Research Working Paper, No. 530, Munich, Germany

30. Hackbart, M. and D. Anderson (1975). On Measuring Economic Diversification. Land Economics, 51(4): 374-8

31. Hall, R. and C. Jones (1999). Why Do Some Countries Produce So Much More Output Per Worker Than Others? Quarterly Journal of Economics, 114(1): 83-116

32. Hall, M. and N. Tideman N. (1967). Measures of Concentration. Journal of the American Statistical Association, 62: 162-8

33. Humphreys, M., J. Sachs and J. Stiglitz (2007). Escaping the Resource Curse. New York: Columbia University Press.

34. Inglehart, R. (1997). Modernization and Postmodernization: Cultural, Economic and Political Change in 43 Societies. Princeton, NJ: Princeton University Press

35. Isham, J., M. Woolcock, L. Pritchett G. Busby (2005). The Varieties of Resource Experience: Natural Resource Export Structures and the Political Economy of Economic Growth. World Bank Economic Review, 19(2):141-174

36. Jacobs, J. (1969). The Economy of Cities. New York, Random House.

37. Jackson, R. (1984). An Evaluation of Alternative Measures of Regional Industrial Diversification. Regional Studies, 18:103-112

38. James, A. and D. Aadland (2011). The Curse of Natural Resources: An Empirical Investigation of US Counties. Resource and Energy Economics 33 (2): 440-53

39. Lane, P. and A. Tornell (1999). The Voracity Effect. American Economic Review, 89:2247

40. Malizia, E. and S. Ke (1993). The Influence of Economic Diversity on Unemployment and Stability. Journal of Regional Science, 33 (2): 221-35

41. Mankiw, N., D. Romer and D. Weil (1992). A Contribution to the Empirics of Economic Growth. Quarterly Journal of Economics, 107(2): 407-37 
42. McLaughlin, G. (1930). Industrial Diversification in American Cities. Quarterly Journal of Economics, 44:131-149

43. Mehlum, H., K. Moene and R. Torvik (2006). Institutions and the Resource Curse. Economic Journal, 116(508): 1-20

44. Nickel, S. (1981). Biases in Dynamic Models with Fixed Effects. Econometrica, 49: 1417-26

45. O'Donoghue, D. (1999). The Relationship between Diversification and Growth: Some Evidence from the British Urban System 1978 to 1991. International Journal of Urban and Regional Research, 23(3): 549-66

46. Palan, N. (2010). Measurement of Specialization -The Choice of Indices. FIW Working Paper No. 062

47. Papyrakis, E. and R. Gerlagh (2007). Resource Abundance and Economic Growth in the United States. European Economic Review, 51(4): 1011-39.

48. Pede, V. (2013). Diversity and Regional Economic Growth: Evidence from US Counties. Journal of Economic Development, 38(3): 111-27

49. Pendergast, S., J. Clarke and G. van Kooten (2011). Corruption, Development and the Curse of Natural Resources. REPA Working Paper No. 2008-10

50. Porter, M. (1990). The Competitive Advantage of Nations. New York: Free Press

51. Porter, M. (1995). The Competitive Advantage of the Inner City. Harvard Business Review, 73(3), 55-71

52. Putnam, R. (1993). Making Democracy Work: Civic Traditions in Modern Italy. Princeton, NJ: Princeton University Press

53. Robinson, J., R. Torvik and T. Verdier (2006). Political Foundations of the Resource Curse. Journal of Development Economics, 79 (2), 447-68

54. Roodman, D. (2009). How to do xtabond2: An Introduction to Difference and System GMM in Stata. Center for Global Development, Working Paper No. 103

55. Ross, M. (2001). Does Oil Hinder Democracy? World Politics, 53: 325-361

56. Sachs, J. and A. Warner (1995). Natural Resource Abundance and Economic Growth. NBER Working Paper No. 5398.

57. Scherer, F.M. (1980). Industrial Market Structure and Economic Performance. Boston: Hougton Mifflin Company 
58. Siegel, P., T. Johnson and J. Alwang (1993a). Economic Diversity and Diversification: A Framework for Analysis? A Paper Prepared for the 40th North American Meetings of the Regional Science Association International, Houston, Texas, November 12-14

59. Siegel, P., T. Johnson and J. Alwang (1993b). Diversification of Production Agriculture across Individual States: A Comment. Journal of Production Agriculture: 6(3) : 445-447

60. Siegel, P., T. Johnson and J. Alwang (1995b). Regional Economic Diversity and Diversification. Growth and Change 26(2):261-284

61. Slack, E., L. Bourne and M. Gertler (2003). Vibrant Cities and City-Regions: Responding to Emerging Challenges. Report Prepared for the Panel on the Role of Government, Toronto.

62. Smith S. and C. Gibson (1988). Industrial Diversification in Nonmetropolitan Counties and Its Effect on Economic Stability. Western Journal of Agricultural Economics, 13(2): 193-201

63. Solow, R. (1956). A Contribution to the Theory of Economic Growth. Quarterly Journal of Economics, 70(1): 65-94

64. Storper, M., Y. Chen and F. De Paolis (2002). Trade and the Location of Industries in the OECD and European Union. Journal of Economic Geography 2(1): 73-107

65. Tauer, L. (1992). Diversification of Production Activities across Individual States. Journal of Production Agriculture, 5:210-4

66. Torres, N., O. Afonso and I. Soares (2013). A Survey of Literature on the Resource Curse: Critical Analysis of the Main Explanations, Empirical Tests and Resource Proxies. CEF.UP Working Paper No. 2013-31

67. Torvik, R. (2002). Natural Resources, Rent Seeking and Welfare. Journal of Development Economics, 67(2): 455-70

68. Traistaru, I., P. Nijkamp and S. Longhi (2002). Regional Specialization and Concentration of Industrial Activity in Accession Countries. ZEI Working Paper, No B:16-34

69. Tran, H. (2011). Industrial Diversity and Economic Performance: A Spatial Analysis. Dissertations and Theses from the College of Business Administration. Paper 19, University of Nebraska.

70. Tress, R. (1938). Unemployment and the Diversification of Industry. The Manchester School, 9:140-152 
71. Wagner, J. and S. Deller (1998). Measuring the Effects of Economic Diversity on Growth and Stability. Land Economics, 74(4):541-560

72. Wagner, J. (2000). Regional Economic Diversity: Action, Concept, or State of Confusion. The Journal of Regional Analysis and Policy, 30 (2): 1-22

73. Windmeijer, F. (2005). A Finite Sample Correction for the Variance of Linear Efficient Two-Step GMM Estimators. Journal of Econometrics, 126(1): 25-51

74. Yamarik, S. (2011). State-Level Capital and Investment: Updates and Implications. Contemporary Economic Policy, 31(1): 62-72 